\title{
Mengemis Sebagai Suatu Pekerjaan
}

\author{
Sahriana Irwan \\ Rosleny Babo \\ Universitas Muhammadiyah Makassar \\ roslenybabo@unismuh.ac.id
}

\begin{abstract}
ABSTRAK
Masalah utama dalam penelitian ini yaitu bagaimanakah mengemis di jadikan sebagai suatu pekerjaan ditinjau dari aspek sosiologi hukum. Penelitian ini adalah jenis penelitian kualitatif, meliputi rangkaian kegiatan yang sistematik untuk mendapatkan jawaban atas permasalahan yang diajukan. Jika dilihat dari jenis dan obyek yang diteliti, maka penelitian ini dikategorikan sebagai penelitian studi kasus dengan maksud memberikan gambaran tentang fenomena mengemis sehingga dijadikan sebagai suatu pekerjaan. Hasil penelitian menggambarkan bahwa menegemis sebagai suatu pekerjaan yang ditinjau dari aspek sosiologi hukum adalah adanya sebuah kompleks penyakit kusta yang berada di Jalan Dangko, dimana masyarakat yang bermukim didalamnya adalah orang-orang yang memiliki keterbatasan fisik dan mental yang tidak normal (penyakit kusta) sehingga untuk memenuhi kebutuhan hidup mereka harus melakukan pekerjaan sebagai pengemis, dan dari aspek sosiologi hukum yang melihat bahwa adanya hubungan timbale balik antara hukum dengan gejala sosial yang dalam potret yang ada sebagian besar dari mereka melanggar norma-norma yang berlaku dalam masyarakat sehingga masalah sosial seperti ini merupakan bahan evaluasi bagi pemerintah untuk meminimalisir para pengemis yang ada dikota Makassar. Dengan memberikan lowongan kerja bagi mereka sesuai dengan kemampuan mereka.
\end{abstract}

Kata Kunci : Profesi, Hukum, Pengemis

\section{PENDAHULUAN}

Kemiskinan dapat dibedakan menjadi tiga pengertian: kemiskinan absolute, kemiskinan relatif dan kemiskinan kultural. Seseorang termasuk golongan miskin absolute apabila hasil pendapatannya berada di bawah garis kemiskinan, tidak cukup untak memenuhi kebutuhan hidup minimum: pangan, sandang, kesehatan, papan, pendidikan. Seseorang yang tergolong miskin relatif sebenarnya telah hidup di atas garis kemiskinan namun masih berada di bawah kemampuan masyarakat sekitarnya. Sedang miskin kultural berkaitan erat dengan sikap seseorang atau sekelompok masyarakat yang tidak mau berusaha memperbaiki tingkat kehidupannya sekalipun ada usaha dari pihak lain yang membantunya. Lebih lanjut, garis kemiskinan merupakan ukuran rata-rata 
kemampuan masyarakat untuk dapat memenuhi kebutuhan hidup minimum. Melalui pendekatan sosial masih sulit mengukur garis kemiskinan masyarakat, tetapi dari indikator ekonomi secara teoritis dapat dihitung dengan menggunakan tiga pendekatan, yaitu pendekatan produksi, pendapatan, dan pengeluaran. Fenomena pengemis telah merebak luas diseluruh kota-kota di Indonesia khususnya kota Makassar. Mereka mengganggu ketertiban umum, seperti kawasan lalu lintas, dipersimpangan lampu merah, hingga mengganggu pejalan kaki.

Ironisnya ada salah satu keluarga yang semua anggota menjadikan mengemis sebagai suatu pekerjaan dan menjadikannya sebagai budaya. Mengemis merupakan salah satu jalan pintas bagi orang miskin untuk memenuhi kebutuhan hidupnya. Ada yang benar-benar tidak mampu sehingga ia harus mengemis dijalanan dan tidak sedikit pula yang berpura-pura mengemis hanya untuk mengambil keuntungan saja. Diluar persoalan agama dan pelanggaran ketertiban umum setiap uang yang diberikan kepada para pengemis membuat mereka merasa dihargai dan menyebabkan menadahkan tangannya kepada orang lain. Sedekah yang kita berikan, justru membuat pengemis semakin tergantung pada orang lain tanpa berusaha untuk mendapatkan sesuatu yang lebih baik dari mengemis. Akhirnya, mereka menjadikan kegiatan mengemis sebagai suatu pekerjaan. Mereka berpikir bahwa mengemis adalah suatu pekerjaan yang menjanjikan walaupun sebenarnya mereka mampu untuk mengambil pekerjaan lebih baik. Karena itu mereka berani melanggar peraturan yang terkait dengan larangan mengemis.

\section{LANDASAN TEORI}

Fenomena kehadiran pengemis merupakan realitas sosial yang berkembang dikota Makassar saat ini. Faktor tersebut didasari oleh keadaan sosial ekonomi keluarga dan tingkat urbanisasi yang tinggi menyebabkan seseorang menjadikan mengemis sebagai suatu pekerjaan untuk mencukupi kebutuhan hidup. Ada tiga gambaran umum pengemis, yaitu sekelompok orang miskin atau orang yang dimiskinkan oleh masyarakat, orang yang disingkirkan dari khalayak ramai, dan orang yang berpola hidup agar mampu bertahan dari kemiskinan, Sangat disayangkan, budaya mengemis yang tumbuh dalam masyarakat Indonesia, bukan hanya dilakukan oleh orang-orang yang benar-benar menghadapi kesulitan hidup, namun dimanfaatkan pula oleh segelintir orang sebagai pekerjaan untuk meraup kekayaan. Banyak cara yang dilakukan para pengemis dalam menjalankan pekerjaannya, baik oleh pengemis yang benar-benar menghadapi kehidupan yang sulit sehingga ia terpaksa mengemis, dan pengemis palsu yang hanya berpura-pura 
miskin. Strategi atau cara-cara yang biasa dipakai para pengemis gadungan hanya berpura-pura. Dalam menjalankan pekerjaannya, mereka menggunakan trik-trik yang dapat menyakinkan orang lain untuk mencari belas kasihan dan memberikan uang. Triktrik yang biasa dipakai adalah sebagai berikut:

1. Menjual kemiskian. Para pengemis biasa berpenampilan kumuh, kotor, dan berpakaian robek-robek atau compang camping. Tampilan seperti itu memberikankesan pada setiap orang yang melihatnya seakan-akan mereka sedang memikul beban berat yang perlu dibantu dan mendorong orang lain untuk memberi.

2. Menampilkan wajah kesedihan. Setiap sepanjang jalan di keramaian kota sering dijumpai pengemis dari anak kecil hingga orang tua yang duduk di pinggir jalan dan mengayunkan tangan dan mereka siap beraksi menampilkan wajah kesedihan yang mendalam, agar membuka hati darmawan untuk memberi.

3. Komunitas pengemis. Komunitas pengemis yaitu kumpulan sejumlah pengemis yang terkoordinasi oleh kordinator yang menempatkan para pengemis-pengemis di wilayahwilayah tertentu, seperti dipusat kota dengan lokasi yang berpindah-pindah dan para pengemis diwajibkan menyetorkan uang hasil mengemis kepada kordinator pengemis yang biasa dikenal bos pengemis.

4. Membawa anak. Membawa anak kecil yang digendong merupakan salah satu trik yang dilakukan pengemis. Anak yang dibawa itu umumnya merupakan anak pinjaman atau sewaan.

Ada banyak faktor yang mendorong orang untuk menjadikan mengemis sebagai suatu pekerjaan, yaitu seperti faktor urbanisasi, faktor ketidakberdayaan, kesulitan ekonomi, Azis Muslimin (2015), menyebutkan ada empat gambaran permasalahn penyebab munculnya pengemis adalah masalah kemiskinan, kemiskinan merupakan faktor dominan yang dapat memaksa seseorang mengemis, serta menjadikannya sebagai suatu pekerjaan, masalah pendidikan, pada umumnya tingkat pendidikan pengemis relative rendah, masalah keterampilan kerja, pada umumnya pengemis tidak memiliki keterampilan yang sesuai dengan tuntutan pasar kerja, masalah sosial budaya, antara lain rendahnya harga diri, sikap pasrah pada nasib (apatis), kebebasan dan kesenangan hidup menggelandang.

Adapun implikasi sosial yang timbul dari mengemis sebagai suatu pekerjaan adalah (1) bagi individu karena mereka yang melakukan pekerjaan tersebut akan merasa malu di dalam masyarakat, kemudian mereka akan dikucilkan. Dan mereka akan merasa terdiskriminasi di dalam masyarakat. (2) Bagi masyarakat karena kegiatan meminta-minta 
yang mereka lakukan jelas mengganggu kenyamanan masyarakat/lingkungan, karena keberadaan mereka yang berada di tempat umum. Tidak sedikit dari mereka memintaminta dengan mengajak anak-anak mereka yang masih balita. (3) bagi Negara karena meminta-minta jelas memiliki dampak negatif terhadap negara kita, karena negara kita dianggap negara yang tidak mampu menjamin kemakmuran hidup warganya, sehingga hal ini menimbulkan masalah sosial yang juga menjadi tanggung jawab negara. Tanggung jawab atas pengemis, mungkin seharusnya menjadi salah satu kewajiban pemerintah apabila kita merujuk pada UUD 1945 Pasal 34 bahwa fakir miskin dan anak-anak terlantar dipelihara oleh negara.

Mengemis adalah kegiatan meminta-minta bantuan, derma, sumbangan baik kepada perorangan atau lembaga yang identik dengan penampilan pakaian yang serba kumal sebagai sarana untuk mengungkapkan kebutuhan apa adanya dan dengan berbagai cara lain untuk menarik simpati orang lain. Cara yang dimaksudkan yaitu dengan mengamen, atau bahkan dengan mengatas namakan suatu yayasan panti asuhan yang ilegal untuk mendapatkan sejumlah uang dari masyarakat. Sedangkan menurut Peraturan Pemerintah No. 31 Tahun 1980, orang-orang yang mendapat penghasilan dengan meminta-minta didepan umum dengan berbagai cara dan alasan dengan mengharapkan belas kasihan dari orang lain disebut dengan pengemis. Mengemis menjadi budaya saat ini, karena banyak sekali orang yang sebenarnya masih dalam keadan sehat memilih jalan untuk mengemis.

Kebutuhan-kebutuhan pengemis ini sering disebut Maslow sebagai kebutuhankebutuhan dasar yang digambarkan sebagai sebuah hierarki atau tangga yang menggambarkan tingkat kebutuhan. Terdapat lima tingkat kebutuhan dasar, yaitu : kebutuhan fisiologis, kebutuhan akan rasa aman, kebutuhan akan rasa memiliki dan kasih sayang, kebutuhan akan penghargaan dan kebutuhan akan aktualisasi diri. Maslow memberi hipotesis bahwa setelah individu memuaskan kebutuhan pada tingkat paling bawah, individu akan memuaskan kebutuhan pada tingkat yang berikutnya. Jika pada tingkat tertinggi tetapi kebutuhan dasar tidak terpuaskan, maka individu dapat kembali pada tingkat kebutuhan yang sebelumnya. Menurut Maslow, pemuasan berbagai kebutuhan tersebut didorong oleh dua kekuatan yakni motivasi kekurangan (deficiency motivation) dan motivasi perkembangan (growth motivation). 


\section{METODE PENELITIAN}

Adapun jenis penelitian yang digunakan ialah deskriptif kualitatif, yaitu penelitian dengan memberikan gambaran secara jelas dan sistematis terkait dengan objek yang diteliti. Penentuan informan dalam penelitian ini dilakukan dengan teknik snowball, atau dikenal dengan teknik bola salju, dan juga menggunakan sumber data primer dan data sekunder, teknik pengumpulan data yaitu observasi, wawancara dan dokumentasi, kemudian dianalisis melalui tahapan pengorganisasian data, pengelompokan data, menguji asumsi terhadap permasalahan yang ada terhadap data, mencari alternatif penjelsan data, menuliskan hasil penelitian, sedangkan teknik keabsahan datanya menggunakan triangulasi sumber, waktu dan teknik.

\section{PEMBAHASAN}

\section{Mengemis dijadikan sebagai suatu pekerjaan ditinjau dari aspek sosiologi hukum}

Ada beberapa faktor yang menyebabkan seseorang mengemis terkhusus didaerah Dangko kelurahan balang baru adalah faktor fisik dimana seseorang mengemis karena keadaan fisik mereka yang tidak sempurna (penderita kusta), yang tidak mampu melakukan pekerjaan lain seperti bekerja di pertokoan. Faktor ekonomi, ekonomi adalah ilmu yang mempelajari upaya manusia dalam memenuhi kebutuhan hidupnya, baik secara perorangan maupun kelompok dengan mempergunakan segala perangkat fasilitas yang berhubungan dan mendukung usaha dilakukannya kegiatan ekonomi, dengan maksud agar memperoleh kesejahteraan atau kemakmuran. Kebutuhan adalah segala sesuatu yang dibutuhkan manusia untuk mempertahankan hidup serta untuk memperoleh kesejahteraan dan kenyamanan. Untuk memenuhi kebutuhan, kesejahteraan hidup seseorang adalah hanya dengan melakukan pekerjaan mengemis karena melihat kondisi fisik mereka yang tidak sempurna yang tidak dapat bekerja selain dari mengemis. Faktor ketidakberdayaan, ketidak berdayaan orang-orang yang mengalami kesulitan untuk memenuhi kebutuhan keluarga sehari-hari karena mereka memang tidak punya gaji tetap. Sementara mereka sendiri tidak memiliki keterampilan atau keahlian khusus yang dapat mereka manfaatkan untuk menghasilkan uang, seperti orang-orang yang menyandang cacat, orang-orang yang menderita sakit sehingga tidak dapat bekerja selain mengemis, karena itulah mereka menjadikan mengemis sebagai pekerjaan.

Dilihat dari beberapa faktor diatas maka ada beberapa implikasi sosial yang ditimbulkan baik yang bersifat positif. Seperti, implikasi yang pertama adalah pendidikan 
anak-anak mereka terjamin. Pendidikan adalah suatu proses yang dilakukan secara sadar atau disengaja guna untuk menambah pengetahuan, wawasan serta pengalaman untuk menentukan tujuan hidup sehingga bisa memiliki pandangan yang luas untuk kearah depan lebih baik dan dengan pendidikan itu sendiri dapat menciptakan orang- orang berkualitas. Seperti beberapa orang yang hanya dengan mengemis, mereka dapat menyekolahkan anak-anak mereka mulai dari SD sampai ke jenjang yang lebih tinggi seperti Universitas dan akhirnya anak tersebut sudah mulai bekerja di sebuah kantor pemerintahan. Implikasi yang kedua adalah dengan bekerja sebagai pengemis mereka mampu memenuhi kebutuhan keluarga sehari-hari, mulai dari makanan, pakaian maupun kebutuhan lainnya. Namun disisi lain dari implikasi positif terdapat pula implikasi negative yang ditimbulkan oleh seseorang yang menjadikan mengemis sebagai pekerjaan adalah mendapat cibiran, hinaan dan keterasingan. Selain itu mereka pun sering mendapat rasia dari pemerintah dinas sosial dan satpol PP yang sedang bertugas mengemankan dan menertibkan kota khususnya kota Makassar.

\section{Penegakan hukum yang mengatur kegiatan mengemis}

a. Peraturan Daerah

Untuk menghilangkan atau meminimalisir pengemis, gelandangan dan anak jalanan, Dinas Sosial kota Makassar telah mengeluarkan peraturan daerah tentang pembinaan pengemis. Peraturan daerah ini tidak hanya mengatur pembinaan, tetapi juga mengatur pelarangan kepada masyarakat untuk member uang kepada para pengemis. Masyarakat akan diajak untuk terbiasa member atau menyumbangkan uang melalui lembaga-lembaga resmi. Dalam peraturan daerah ini juga telah diatur sanksi bagi yang member uang kepada pengemis.

b. Hukum Islam

Hukum syariat (terdapat dalam Alqur'an dan hadits) yang berkaitan dengan perbuatan subjek hukum, berupa melakukan sesuatu perbuatan memilih atau menentukan sesuatu sebagai syarat, sebab, atau penghalang. Dalam pokok ajaran islam ada beberapa hal yang melarang mengemis itu dijadikan sebagai pekerjaan, diantaranya ialah (1) Haram jika pengemis yang melakukan pekerjaan itu setiap hari memang sudah menjadi kebiasaannya, namun banyak pandangan dari sebagian orang hal itu sangat hina. Mengemis bisa haram hukumnya jika dari sebagian mereka hanya untuk memanfaatkan harta orang lain. Dan juga untuk memperkaya diri semata, sementara ia mampu melakukan pekerjaan lain. (2) Mubah jika si pelaku mengalami cacat yang tidak mungkin 
ia bisa melakukan pekerjaan yang lain, atau bagi mereka yang sudah tidak memiliki apaapa lagi maka jalan mengemis bisa mubah hukumnya bagi mereka.

\section{KESIMPULAN}

Berdasarkan hasil penelitian yang telah disajikan dalam pembahasan pada bab terdahulu, maka dapat ditarik suatu kesimpulan bahwa mengemis di jadikan sebagai suatu pekerjaan ditinjau dari aspek sosiologi hukum dalam hal ini mengemis merupakan gejala sosial yang mempunyai hubungan timbal balik dengan hukum. Mengemis sudah menjadi budaya yang mengakar tidak hanya itu keterbatasan fisik dan mental yang tidak normal dan kebutuhan sehari-hari yang tidak mampu mencukupi kebutuhan mereka yang mengharuskan mereka untuk bekerja sebagai pengemis, disisi lain mereka menganggap bahwa pekerjaan mengemis merupkan pekerjaan yang mudah untuk mendapatkan uang, tidak hanya itu sebagian dari mereka juga menyepelekan norma-norma hukum yang berlaku di masyarakat misalnya mengganggu ketertiban lalu lintas. Mengemis juga membuat mereka malas untuk bekerja. Faktor penyebab seseorang mengemis adalah faktor fisik, faktor ekonomi, dan faktor ketidakberdayaan. Implikasi yang ditimbulkan dari mengemis sebagai pekerjaan adalah pendidikan anak dapat terjamin, kebutuhan sehari-hari/ekonomi dapat terpenuhi. Ada implikasi negative seperti mendapat cibiran, terasingkan/dimarginalisasikan, mengganggu ketertiban umum dan keindahan kota serta mendapat rasia. Solusi yang dapat meminimalisir pengemis adalah memberikan bantuan berupa modal usaha, mendirikan organisasi yang dapat membantu mereka seperti rumah baca sehingga mereka mampu berpikir lebih baik sehingga tidak melakukan pekerjaan mengemis. Dan dapat member pendidikan keterampilan seperti membuat keset kaki.

\section{DAFTAR PUSTAKA}

Adi, Isbandi Rukminto. (2013). Kesejahteraan Sosial (Pekerjaan Sosial, Pembangunan Sosial, dan Kajian Pembangunan). Jakarta : PT. RajaGrafindo Persada.

Akbar, Ali. (2004). Upaya Mengurangi Kemiskinan Pada Masyarakat Pedesaan Studi Kasus Peran PNPM Mandiri Di Desa Raja Kecamatan Kajuara Kabupaten Bone (Skripsi). Makassar : UNM

Alvin S., Johnshon. (2004). Sosiologi Hukum. Jakarta: Rineka Cipta

Bagong Suyanto Dan Dwi Narwoko. (2004). Sosiologi Teks Pengantar Dan Terapan. Surabaya: Kencana 
Darwin, Sudarman. (2002). Menjadi Peneliti Kualitatif. Bandung : CV Pustaka Setia.

Elly M. Setiadi Dan Usman Kolip. (2011). Pengantar Sosiologi. Jakarta : Kencana Prenada Media Grup

Fadillah. (2012). Hukum Mengemis Sebagai Profesi.(online). http//: hukum-mengemissebagai-profesi\%20.html (di akses tanggal 10 Mei 2015)

Lawang, Robert M.Z. (1986). Teori Sosiologi Klasik Dan Modern. Jakarta : PT Gramedia

Muslim. (2013). Profesi Mengemis. (online). http/l:fiqh-dan-muamalah-profesipengemis.html. (diakses tanggal 10 Mei 2015)

Muslimin, Abdul Aziz. (2006). Anak Jalanan di Kota Makassar (Studi Pemberdayaan Anak Jalanan di Rumah Singgah). Tesis. Makassar : UNM

PPs UNM. Makassar

(2015). Perilaku Sosial Pengemis di Kota Makassar. Disertasi

Pudjiwati, Sajogyo. (2002). Sosiologi Pedesaan. Jogjakarta : Gajah Media University Press.

Ritzer George. (1992). Sosiologi ilmu pengetahuan berparadigma ganda. Jakarta :

Rajawali Pers

Saebani, Beni Ahmad. (2007). Sosiologi Hukum. Bandung : Pustaka Setia.

Soerjono, Soekanto. (1990). Sosiologi Suatu Pengantar. Jakarta: Rajawali Press.

Soerjono, Soekanto. (1982). Suatu Tinjauan Sosiologi Hukum Terhadap MasalahMasalah Sosial. Bandung : Alumni.

Soerjono, Soekanto dan Mustafa Abdullah. (1982). Sosiologi Hukum Dalam Masyarakat. Jakarta: Rajawali Press.

Sajipto, Rahardjo. (2010). Sosiologi Hukum (Perkembangan Metode dan

Pilihan Masalah). Yogyakarta : Genta Publishing.

Suharto, Edi. (2014). Membangun Masyarakat Memberdayakan Rakyat. Bandung : PT. Refika Aditama

Sumardi, Mulyanto. (1982). Kemiskinan dan Kebutuhan pokok. Cet II. Jakarta : CV Rajawali

Sunarto, Kamanto. (1993). Pengantar sosiologi. Jakarta : Lembaga Penerbit Fakultas Ekonomi Universitas Indonesia

Syekhu. (2009). Tinjauan Sosiologi Hukum Perilaku Gelandang, Pengemis, Anak-anak Terlantar Di Kota Makassar.(online). http//:tinjauan-sosiologi-hukum-perilaku- 
gelandangan-pengemis-dan-anak-anak-terlantar-di-kota-makassarjaringskripsi.htm. (di akses tanggal 17 Mei 2015)

Utsman, Sabian. (2009). Dasar-Dasar Sosiologi Hukum (Makna Dialog Antara Hukum dan Masyarakat).Yogyakarta : Pustaka Pelajar

Umiarso \& Elbadiansyah. (2014). Interaksionisme Simbolik Dari Era Klasik Hingga Modern. Jakarta : PT. RajagrafindoPersada

Wirawan, I.B. (2012). Teori-Teori Sosial Dalam 3 Paradigma. Jakarta : Kencana 